\title{
Physiological Response of Pseudomonas Fluorescens to the Dodecyldimethylamine Oxide in the Presence of a Washing Formulation
}

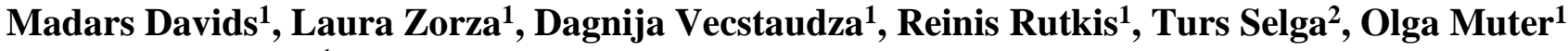 \\ ${ }^{1}$ Institute of Microbiology \& Biotechnology, University of Latvia \\ 1 Jelgavas Str., Riga LV-1004, Latvia \\ sradamsdivad@gmail.com; lau.ra@inbox.lv; dagnijave@gmail.com; reinis.rutkis@lu.lv; olga.mutere@lu.lv \\ ${ }^{2}$ Faculty of Biology, University of Latvia \\ 1 Jelgavas Str., Riga LV-1004, Latvia \\ turs.selga@lu.lv
}

\begin{abstract}
Quaternary ammonium compounds (QAC) are unique surfactants, which are widely used as biocides for numerous industrial purposes. An efficiency of disinfectant is highly dependent on the physicochemical properties of environment. The aim of this study was to evaluate the antibacterial effect of the widely used QACs, i.e. $N, N$-dimethyldodecan-1-amine oxide (DDAO) in mixture with the commercially available surface washing formulation (WF). Pseudomonas fluorescens served as a test organism. The changes in kinetic parameters of bacterial growth, optical density, ATP concentration in the batch cultures, as well as morphological changes of cells were monitored in order to evaluate a physiological response of bacterial cultures to the different combinations of the tested chemicals. A decrease of WF concentration in the broth from $0.1 \%$ to $0.02 \%$ resulted in a gradual reducing the lag period in the presence of $0.03 \%$ DDAO, while the specific growth rate did not depend on the WF concentration. Comparison of the effect of ATP concentration and the $\mathrm{OD}_{620}$ has revealed the differences in cells response to the presence of WF and DDAO. It was concluded that the antibacterial effect of QACs, particularly DDAO, is highly dependent on the composition of washing formulations, which can notably reduce the efficiency of the added QACs.
\end{abstract}

Keywords: ATP; Fluorescence; Quaternary ammonium salts (QAS); Pseudomonas fluorescens; Specific growth rate; Washing formulations (WF).

\section{Introduction}

Quaternary ammonium compounds (QAC) are unique surfactants that act as detergents, antistatic agents, oil in-water emulsifiers, corrosion inhibitors, lubricants, as well as disinfectants [1]. QACs are widely used as biocides for numerous industrial purposes, water treatment, antifungal treatment in horticulture, as well as in pharmaceutical and everyday consumer products as preserving agents, foam boosters, and detergents [2]. The probable production of QAC's per year in the EU is more than 1000 tons of pure compounds, several of the individual compounds being produced at more than 10 tons per year [3]. These objectives lead to an increasing attention of chemists and microbiologists in order to develop the new QACcontaining formulations, which would be efficient and environmentally safe.

The antimicrobial mechanism of QAC is rather specific. They cause damage to the cytoplasmic membrane due to perturbation of the bilayers by the molecules' alkyl chains [4]. QACs interfere with normal ammonium uptake, as well as irreversibly bind to the phospholipids and proteins of the membrane, thereby impairing permeability [5].

In particular, antibiotic resistance has emerged in microorganisms due to excessive use of QACs in household and industrial applications, veterinary hygiene, food industries and environments [6]. Buffet-Bataillon and coauthors [7] reported about the epidemiological relationship between higher MIC values of QACs in clinical E. coli isolates and antibiotic resistance. Earlier studies have also demonstrated that adaptation or resistance to QACs can develop [8][9][10].

Addition of QACs to the preparation might change its physicochemical and antimicrobial properties. Synergistic combination of cationic biocide and QAC in antimicrobial compositions with the ratio less of 1:10 was discovered by [11]. The combination of the QAC $(0.1-10 \% \mathrm{w} / \mathrm{w})$, the nonionic surfactant $(0.1-10 \% \mathrm{w} / \mathrm{w})$ and glycol ether solvent $(3.5-10 \% \mathrm{w} / \mathrm{w})$ has been found to provide a synergistic effect, where an acceptable cleaning efficacy and a broad spectrum of antimicrobial 
activity remained even at the decreased QAC concentrations [12]. Combinations of chlorinated phenols and an antimicrobial alcohol (e.g., propen-2yl-methyl-cyclohexanols) showed a greater antimicrobial activity than it would be observed for the individual constituents [13].

So, understanding the mechanisms and conditions that result in QAC efficiency as antimicrobials in complex cleaning formulations will lead to the development of more efficient and safer disinfectants [14]. For that purpose, culture-dependent and non-culture-dependent tools, as well as advanced analytical techniques should be applied [15]. The measuring methodology, including the standardized procedures, as well as the interpretative criteria for evaluating susceptibility test results, not always describe the real processes occurred with microbial cells in the presence of disinfectants.

One of the well-known detergents and solubilizing agents, which is widely used for surfactant-based aqueous preparations is $N, N$-dimethyldodecan-1-amine oxide (DDAO) [16].

The aim of this study was to evaluate the antibacterial effect of DDAO in mixture with the commercially available surface washing formulation (WF). Pseudomonas fluorescens A11 served as the test organism. The changes in optical density, ATP concentration in the batch cultures, as well as morphological changes of cells were monitored in order to evaluate a physiological response of bacterial cultures to the different combinations of the tested chemicals.

\section{Materials and Methods}

\subsection{Washing Formulation and Quaternary Ammonium Salt}

The tested WF belongs to the group of waterless surface washing formulations. Composition of this product is complex and contains three key compounds, i.e., i) Compound $\mathrm{A}$ - high viscosity silicone and wax mixture; ii) Compound $\mathrm{B}$ surfactants as amine $\mathrm{N}$-oxide, alkylene derivatives of higher alcohols and benzylammonium alkylderivatives; iii) Compound $\mathrm{C}$ - organic solvent $3-10 \%$ and water $0-5 \%$ of the total composition [17]. The cationic surfactant representing the quaternary ammonium salt, i.e., $N, N$ - Dimethyldodecan-1-amine oxide, $\mathrm{C}_{14} \mathrm{H}_{31} \mathrm{NO}$, or dodecyldimethylamine oxide (DDAO) (Sigma, $30 \%$ in water) was used.

\subsection{Bacterial Culture and Cultivation}

Pseudomonas fluorescens AM11 was obtained in the culture collection of the Institute of Microbiology \& Biotechnology, University of Latvia. Composition of the broth was as follows, g/L: $\mathrm{Na}_{2} \mathrm{HPO}_{4} \times 12 \mathrm{H}_{2} \mathrm{O}-6.0 ; \mathrm{KH}_{2} \mathrm{PO}_{4}-3.0$; $\mathrm{NaCl}-0.5 ;\left(\mathrm{NH}_{4}\right)_{2} \mathrm{SO}_{4^{-}} 0.3 ; \mathrm{Fe}_{2} \mathrm{SO}_{4} \times 7 \mathrm{H}_{2} \mathrm{O}-0.002 ; \mathrm{Na}_{2} \mathrm{MoO}_{4}-0.001$; glucose - 10.0; yeast extract - 2.0. Bacterial cultures were incubated on a rotary shaker $\left(30^{\circ} \mathrm{C}, 180 \mathrm{rpm}\right)$.

\subsection{Measurement of $O D_{620}$ and Fluorescence}

The optical density $\left(\mathrm{OD}_{620}\right)$ of bacterial cultures was measured in Tecan Infinite ${ }^{\circledR} 200$ PRO. $100 \mu \mathrm{L}$ broth with amendments and $100 \mu \mathrm{L}$ overnight culture of $P$. fluorescens $\left(5.1 * 10^{6} \mathrm{CFU} / \mathrm{mL}\right)$ were added to the wells, according to the experiment scheme, each variant in triplicate. The plates were incubated at $30^{\circ} \mathrm{C}$, with shaking orbital duration and amplitude of $490 \mathrm{~s}$ and $3.5 \mathrm{~mm}$, respectively.

\subsection{Determination of Specific Growth Rate}

Bacterial specific growth rate (SGR) was mathematically calculated using $\mathrm{OD}_{620}$ values which were previously measured in Tecan Infinite 200 PRO series microplate reader by equation (1):

$$
\mu=\frac{\ln \frac{O D_{620} t 2}{O D_{620} t 1}}{t 2-t 1} \text { where } \mu=\text { Specific Growth Rate; }
$$

$\mathrm{OD}_{6200} \mathrm{t} 2=\mathrm{OD}_{620}$ value at the end of bacteria exponential growth phase;

$\mathrm{OD}_{620} \mathrm{t} 1=\mathrm{OD}_{620}$ value at the start of bacteria exponential growth phase;

$\mathrm{t} 2=$ time of occurrence of exponential phase end point;

$\mathrm{t} 1=$ time of occurrence of exponential phase end point. 


\subsection{Confocal Laser Scanning Microscopy}

Cells were fixed with $96 \%$ ethanol and stained with propidium iodide (PI) in a concentration of $20 \mu \mathrm{M} / \mathrm{mL}$. Samples were analysed using the confocal laser scanning microscope Leica DM RA-2 (Germany) equipped with a TCS-SL confocal scanning head. PI was excited with a $488 \mathrm{~nm}$ band and fluorescence was detected between $600 \mathrm{~nm}$ and $640 \mathrm{~nm}$.

\subsection{ATP concentration}

ATP was determined by measuring bioluminescence using the ATP bioluminescence assay kit CLS II from Roche ${ }^{\circledR}$ by following manufacturer instructions. ATP concentration was measured in Tecan Infinite ${ }^{\circledR} 200 \mathrm{PRO}$ at $16{ }^{\circ} \mathrm{C}$. Five $\mu \mathrm{L}$ of bacterial suspension, which was previously diluted with trichloroacetic acid (1:1) were filled in the well. After that, $45 \mu \mathrm{L}$ buffer was added. During experimental procedure $50 \mu \mathrm{L}$ of luciferase reagent was automatically added to each well. The amount of ATP present in the sample was quantified as relative light units (RLU) emitted during the enzymatic reaction. Linear calibration curve was made by using ATP standard concentrations.

\subsection{Statistical Analysis}

Mean values and standard deviations were calculated using Microsoft Word Excel. The significance of differences among the treatments was calculated using the t-test in program R (significance level 0.05).

\section{Results}

\subsection{Kinetic Parameters of the Bacterial Growth in the Broth Amended with WF and DDAO in Different Concentrations}

The response of growing cultures of $P$. fluorescence to WF and DDAO was evaluated by two parameters, i.e., the period of lag phase and SGR. As shown in Fig.1A, the longest lag phase for a bacterial culture was detected in the presence of 0.1 $\% \mathrm{WF}$ and $0.03 \%$ DDAO. A decrease of WF concentration in the broth from $0.1 \%$ to $0.02 \%$ resulted in a gradual reducing the lag period from $13.5 \mathrm{~h}$ to $10.8 \mathrm{~h}$ (Fig.1A). Conversely, the values of SGR in the presence of $0.03 \%$ DDAO did not depend on the WF concentration and varied in the range from 0.03 to 0.07 (Fig.1B).
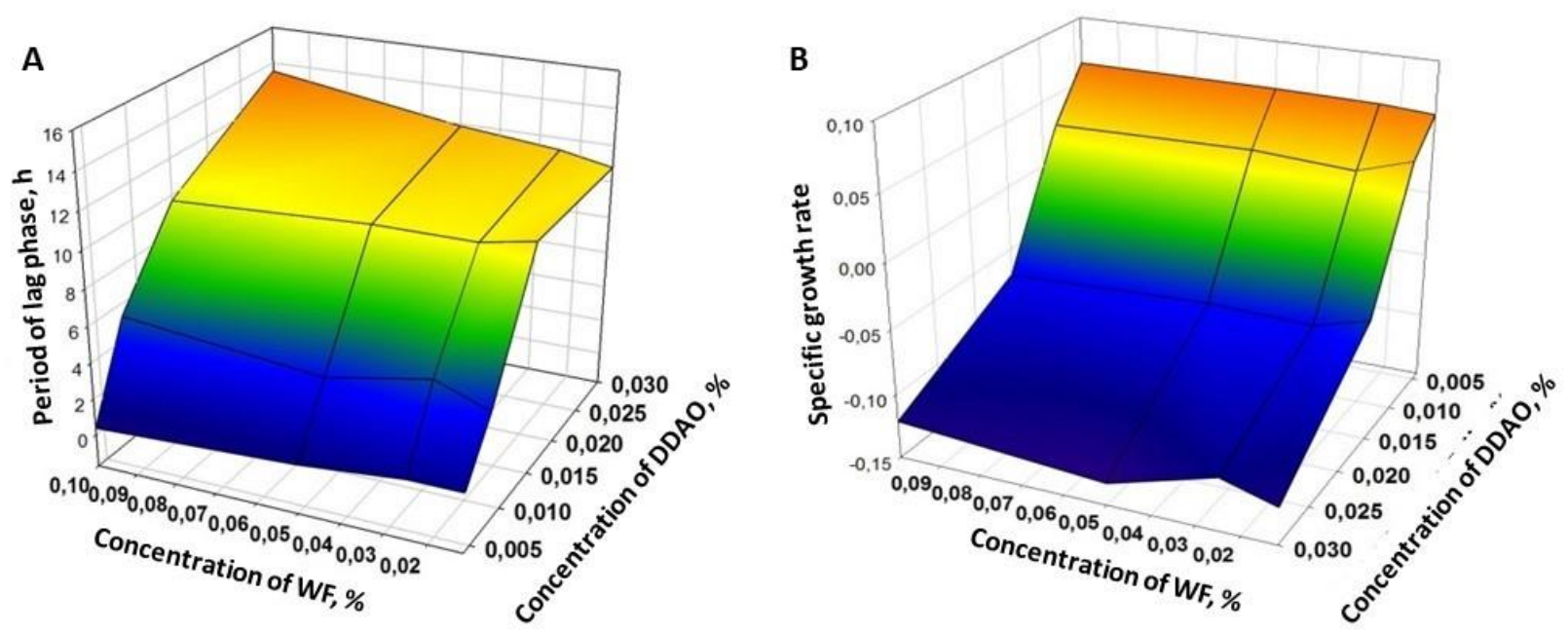

Fig. 1: Effect of DDAO and WF on the lag phase length (A) and specific growth rate (B) of the P. fluorescence culture. 


\subsection{The $\mathrm{OD}_{620}$ of the Cultures after $90 \mathrm{~h}$ Cultivation}

The data presented in Fig.1 summarize a bacterial response to the WF and DDAO within the first 20h incubation. Among the physiological reactions of the tested cultures was a prolonged lag phase, which indicated to the delay in cell proliferation. The next series of experiments was performed with a longer period of incubation, i.e., $90 \mathrm{~h}$. As shown in Figure 2, the growth of $P$. fluorescens culture was totally inhibited in the presence of $1 \% \mathrm{WF}$. The similar effect was found also for the set with $0.03 \%$ DDAO. However, combination of $0.1 \%$ or $0.01 \%$ WF with $0.03 \%$ DDAO resulted in a growth recovery $\left(\mathrm{OD}_{620}\right.$ 0.19 and 0.23 , respectively) of bacterial cells after $90 \mathrm{~h}$ cultivation. The $\mathrm{OD}_{620}$ of the control set was 0.43 (Fig.2).

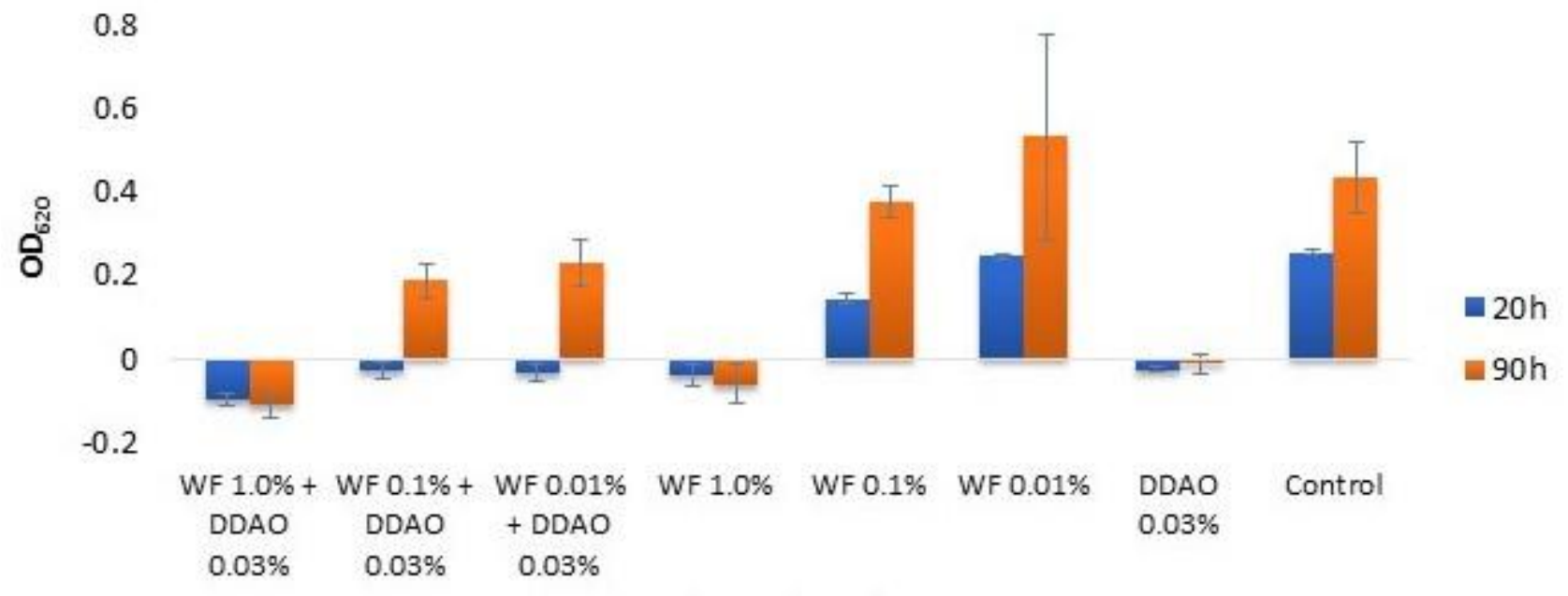

\section{Amendments}

Fig. 2: Optical density the P. fluorescence cultures after $20 \mathrm{~h}$ and $90 \mathrm{~h}$ cultivation in the presence of $0.3 \%$ DDAO and $0.1 \% \mathrm{WF}$.

\subsection{Concentration of ATP in the Bacterial Cultures after $90 \mathrm{~h}$ Growth in the Presence of WF and DDAO}

ATP is the main energy source for enzymatic reactions, and it is essential for every metabolically active microbial cell. Cells can vary in their ATP content according to cell size, species, physiological state or stress condition [18][19][20]. Taking into consideration the $\mathrm{OD}_{620}$ values after $90 \mathrm{~h}$ cultivation (Fig.2), it was expected that ATP concentration was lower in the sets, where the growth was inhibited. The concentrations of ATP in P. fluorescens cultures are shown in Fig.3A. The lowest concentration of ATP was detected in the broth with $0.03 \%$ DDAO, while the highest - in the broth with WF $0.1 \%$, i.e., $0.23 \mu \mathrm{M}$ ATP and $1.44 \mu \mathrm{M}$ ATP, respectively (Fig.4A). The data on ATP concentration and $\mathrm{OD}_{620}$ values obtained for the sets amended with WF and DDAO, have been presented as the ratio to the values in non-amended sets. Thus, the ATP concentration in the broth with $0.1 \%$ WF was $14 \%$ higher than in the control, while the $\mathrm{OD}_{620}$ in this variant was $14 \%$ lower, than in the control (Fig.3B). The similar trend was observed also for the broth with [0.1\% WF and 0.03\% DDAO], where the ATP concentration was lower only for $28 \%$, while $\mathrm{OD}_{620}-56 \%$, as compared to the control. Conversely, in the presence of $0.03 \%$ DDAO without WF the ATP concentration was more sensitive than $\mathrm{OD}_{620}$, and was $92 \%$ and $47 \%$ lower than in control, respectively (Fig.3B).

As was reported earlier, DDAO may stimulate the ATPase activity of Escherichia coli [21][22][23]. 


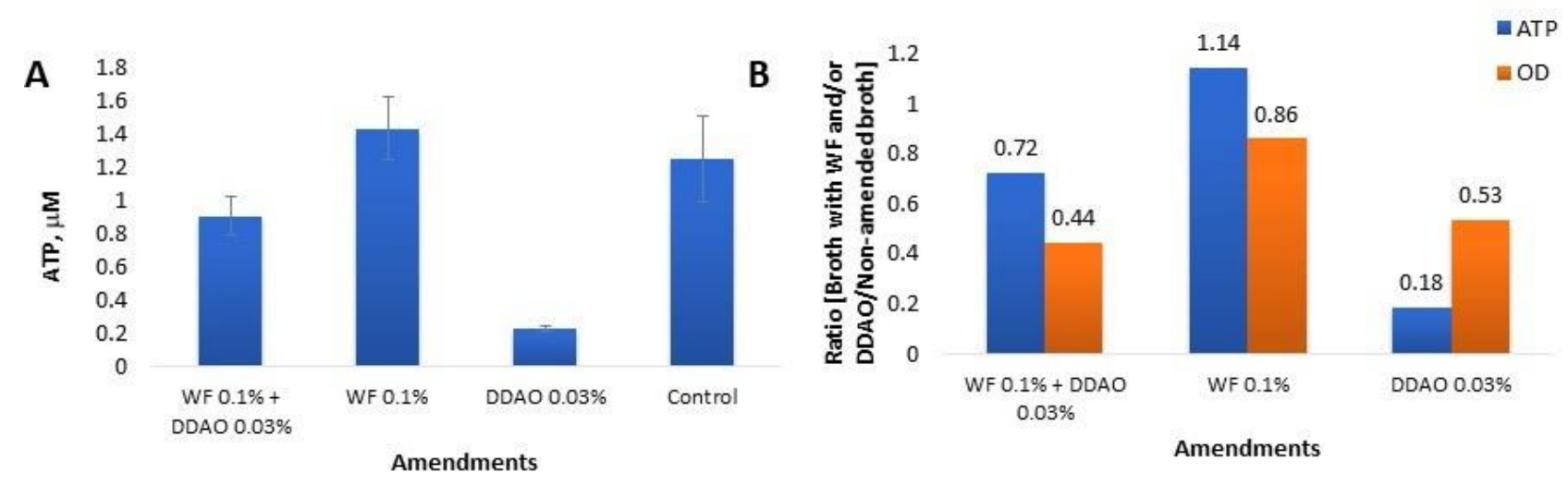

Fig. 3: ATP concentration in the cultures of $P$. fluorescens after $90 \mathrm{~h}$ cultivation in the broth amended with WF and DDAO. A ATP concentration; $\mathrm{B}$ - ratio of the ATP concentration/ $\mathrm{OD}_{620}$ values in the cultures grown in the presence of WF or/and DDAO to those grown without amendments (control).

\subsection{Effect of WF on Cell Morphology}

The confocal laser scanning microscopy was used for visualization of cells morphology in $P$. fluorescens cultures. As shown in Fig.4, the presence of WF in the broth considerably altered the cells morphology in the culture after 90h cultivation. Specifically, cell elongation in the presence of $0.05 \%$ WF has been detected, comparing with the cells grown in a nonamended broth (Fig.4).
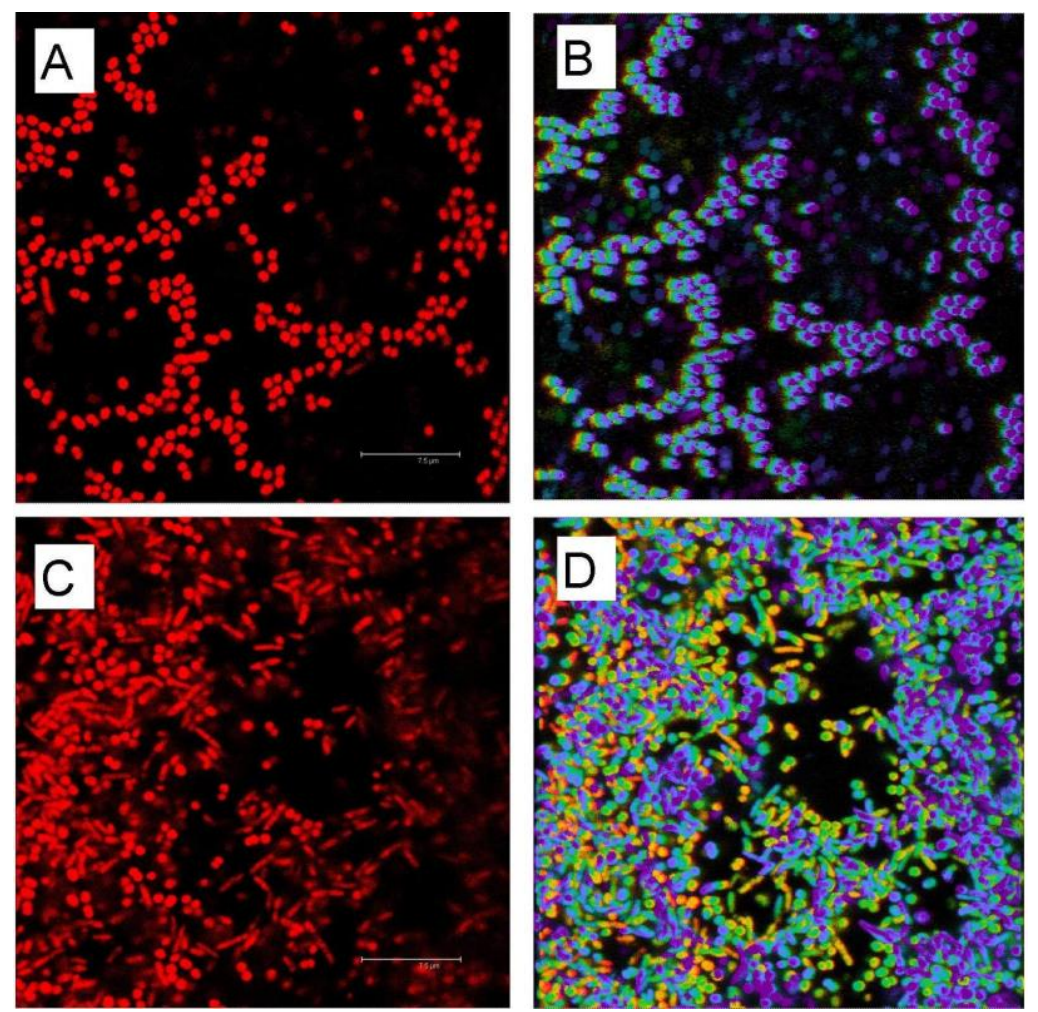

Fig. 4: Confocal laser scanning micrographs of P.fluorescens after incubation in the unamended broth $(\mathrm{A}, \mathrm{B})$ and in the presence of $0.05 \% \mathrm{WF}(\mathrm{C}, \mathrm{D})$. Period of incubation $90 \mathrm{~h}$. Scanned along xyz axes $(10 \mu \mathrm{m}), 20$ optical sections. Objective $-100 x, \mathrm{NA}-1,25$. Bar $=7.5 \mu \mathrm{m}$. B,D - color coded 3D projection. Blue corresponds to the top, green to the middle and red to the bottom of the specimen. 


\section{Discussion}

It is well known, that an efficiency of disinfectant is highly dependent on the physicochemical properties of environment. Surface care preparations may contain surfactants, solvents, organotropic and hydrotropic agents, softening, antistatic, optical brightening and other agents.

Microbial resistance towards QACs is known to be facilitated by several mechanisms such as modifications in the membrane composition, expression of stress response and repair systems, or expression of efflux pump genes [2]. In our study, this phenomenon can be caused by a presence of WF's compound(s), which either i) smoothes the attack of QAC to the cell wall by formation of a protective layer around the cell or/and ii) reacts directly with QAC, thus, neutralizing its antibacterial activity.

The WF used in this study, belongs to the market group of surface care products and possesses a strong antibacterial effect, most probably due to the presence of different QACs. Our previous studies showed its inhibition effect for a battery of test-organisms, ranging the MIC values in the following order: Thamnocephalus platyurus $(0.001 \%)>$ Selenastrum capricornutum $(0.01 \%)>$ P.fluorescens $(0.05 \%)>$ Lepidium sativum $(0.6 \%)$ [24].

Another important issue for discussion is a methodical approach. Studies on efficiency of QACs and complex disinfecting formulations, using the standard suspension test and not under practical conditions can be considered as a strong limitation leading to the overestimation of disinfection effect. In case the efficiency of a disinfectant applied to surfaces is based on counting the microbial survivors sampled in a liquid, the total cell removal from surfaces is seldom achieved [25]. Additional parameters of bacterial physiological activity is highly desirable.

Analysis and interpretation of the results is limited by a shortage of information on the chemical composition of WFs. Usually it is not disclosed by a manufacturer, hence, the changes of disinfection properties of two or more surface care products, which were simultaneously applied on the surface, - cannot be predicted. Disinfecting a surface comprises of the applying a cleaning/disinfecting composition and its removing afterwards. Step of removing the compositions comprises rinsing the surface with a suitable solvent or wiping the surface with a suitable wipe. Traces of the composition may remain on the surface [13]. In this context, stimulation of bacteria by highly diluted disinfectants and washing compositions, as was demonstrated for DDAO, - should be studied further under variable conditions.

\section{Conclusions}

The results of this study indicated that the antibacterial effect of DDAO is dependent on the composition of the main washing formulation and the data on a bacterial response differed when different evaluation criteria were used. Particularly, the following conclusions were made:

1. In the presence of $0.03 \% \mathrm{DDAO}$ and different concentrations of WF, the lag period of the P. fluorescens culture was reduced at higher WF concentrations, while the values of SGR did not depend on the WF concentration.

2. The growth of $P$. fluorescens culture was totally inhibited in the presence of $0.03 \%$ DDAO. However, combination of $0.1 \%$ or $0.01 \% \mathrm{WF}$ with $0.03 \%$ DDAO resulted in a growth recovery of bacterial cells after 90h cultivation.

3. The effect of WF and DDAO on the $\mathrm{OD}_{620}$ did not correlate with the changes in ATP concentration in the same culture.

4. Cultivation of P. fluorescens in the presence of WF resulted in changing the cell morphology. This fact indicated to the shift in cell physiology and metabolism, and hence, possible alterations in cells resistance towards antibacterial compounds (e.g., DDAO).

\section{Acknowledgements}

This study was financed by the project "Sustainable use of nature resources in the context of climate change" (ZD2016/AZ03). 


\section{References}

[1] R. von Wandruszka, "Detergency of Specialty Surfactants". Surfactant Science Series. Volume 98 Edited by Floyd E. Friedli (Goldschmidt Chemical Corp., Dublin, OH). Marcel Dekker, Inc.: New York, Basel. 2001. x + 284 pp. ISBN 0-8247-0491-6., J. Am. Chem. Soc. (2001). doi:10.1021/ja015250+.

[2] K. Hegstad, S. Langsrud, B.T. Lunestad, A.A. Scheie, M. Sunde, S.P. Yazdankhah, "Does the wide use of quaternary ammonium compounds enhance the selection and spread of antimicrobial resistance and thus threaten our health?", Microb. Drug Resist. (2010). doi:10.1089/mdr.2009.0120.

[3] Scenihr, "Assessment of the Antibiotic Resistance Effects of Biocides", Report. (2009). doi:10.2772/8624.

[4] S. Wessels, H. Ingmer, "Modes of action of three disinfectant active substances: A review", Regul. Toxicol. Pharmacol. (2013). doi:10.1016/j.yrtph.2013.09.006.

[5] S. Buffet-Bataillon, P. Tattevin, M. Bonnaure-Mallet, A. Jolivet-Gougeon, "Emergence of resistance to antibacterial agents: The role of quaternary ammonium compounds - A critical review", Int. J. Antimicrob. Agents. (2012). doi:10.1016/j.ijantimicag.2012.01.011.

[6] C. Zhang, F. Cui, G. ming Zeng, M. Jiang, Z. zhu Yang, Z. gang Yu, M. ying Zhu, L. qing Shen, "Quaternary ammonium compounds (QACs): A review on occurrence, fate and toxicity in the environment", Sci. Total Environ. (2015). doi:10.1016/j.scitotenv.2015.03.007.

[7] S. Buffet-Bataillon, B. Branger, M. Cormier, M. Bonnaure-Mallet, A. Jolivet-Gougeon, "Effect of higher minimum inhibitory concentrations of quaternary ammonium compounds in clinical E. coli isolates on antibiotic susceptibilities and clinical outcomes", J. Hosp. Infect. (2011). doi:10.1016/j.jhin.2011.06.008.

[8] M. Reichel, A. Schlicht, C. Ostermeyer, G. Kampf, "Efficacy of surface disinfectant cleaners against emerging highly resistant gram-negative bacteria", BMC Infect. Dis. (2014). doi:10.1186/1471-2334-14-292.

[9] S.S. Block, "Disinfection, Sterilization, and Preservation", Soil Sci. (1977). doi:10.1097/00010694-197712000-00013.

[10] J.M. Boyce, D. Pittet, "Guideline for Hand Hygiene in Health-Care Settings: Recommendations of the Healthcare Infection Control Practices Advisory Committee and the HICPAC/SHEA/APIC/IDSA Hand Hygiene Task Force", Infect. Control Hosp. Epidemiol. (2002). doi:10.1086/503164.

[11] B. Herdt, K.R. Smith, R. Staub, K. Tauer, "Wear resistant antimicrobial compositions and methods of use", Patent appl. No. PCT/IB2011/055555, WO 2012080918 A2, 2012.

[12] B.T.G. Graubart, A.L. Streit, E.J. Sachs, C.A. Beronio, " Method for cleaning hard surfaces using an aqueous solution of quaternary ammonium compound, combination of nonionic surfactant and glycol ether solvent", US Patent 08/499,770, publ.No. US5522942 A, 1996.

[13] R.J. Cornmell. M.A. Diehl, S. Golding, J.R. Harp, I.P. Stott, K.M. Thompson, C.L. Truslow, "Microbicidal composition", Patent Appl. No. PCT/EP2012/074409, Publ.No. WO2013083586 A3, 2014.

[14] F. Devínsky, M. Pisárčik, M. Lukáč, Cationic amphiphiles: Self-assembling systems for biomedicine and biopharmacy, 2017.

[15] U. Tezel, S.G. Pavlostathis, Role of Quaternary Ammonium Compounds on Antimicrobial Resistance in the Environment, in: Antimicrob. Resist. Environ., 2011. doi:10.1002/9781118156247.ch20.

[16] M. Baglioni, Y. Jàidar Benavides, D. Berti, R. Giorgi, U. Keiderling, P. Baglioni, An amine-oxide surfactant-based microemulsion for the cleaning of works of art, J. Colloid Interface Sci. (2015). doi:10.1016/j.jcis.2014.10.003.

[17] S. Strikauska, A. Berzins, L. Arbidans, A. Kukela, O. Muter, M. Klavins, Physicochemical Pretreatment of Contaminated Microfibre Cloths after Their Use in Waterless Car Wash / Ar virsmas aktīvām vielām piesārṇotu bezūdens automašīnu tīr̄̌šanas mikrošķiedru audumu fizikāli-ķīmiskā priekšapstrāde., Mater. Sci. Appl. Chem. (2016). doi: $10.1515 / \mathrm{msac}-2015-0015$.

[18] A.T.P. Detection, ATP DETECTION ATP Measurement as a Means for Directly Estimating Active Biomass, Water Res. (2007).

[19] F. Hammes, N. Boon, M. Vital, P. Ross, A. Magic-Knezev, M. Dignum, Bacterial colonization of pellet softening reactors used during drinking water treatment, Appl. Environ. Microbiol. (2011). doi:10.1128/AEM.02068-10.

[20] D.E. Turner, E.K. Daugherity, C. Altier, K.J. Maurer, Efficacy and limitations of an ATP-based monitoring system, J. 
Am. Assoc. Lab. Anim. Sci. (2010).

[21] H.R. Löscher, C. de Jong, R.A. Capaldi, Interconversion of High and Low Adenosinetriphosphatase Activity Forms of Escherichia coli F1 by the Detergent Lauryldimethylamine Oxide, Biochemistry. (1984). doi:10.1021/bi00313a020.

[22] S.D. Dunn, R.G. Tozer, V.D. Zadorozny, Activation of Escherichia coli F1-ATPase by Lauryldimethylamine Oxide and Ethylene Glycol: Relationship of ATPase Activity to the Interaction of the $\in$ and $\beta$ Subunits, Biochemistry. (1990). doi:10.1021/bi00470a011.

[23] A.S. Lapashina, B.A. Feniouk, ADP-Inhibition of H+-FOF1-ATP Synthase, Biochem. (2018). doi:10.1134/S0006297918100012.

[24] D. Vecstaudza, M. Klavins, O. Muter, R. Rutkis, Toxicity Evaluation of Surface Cleaning Preparation Using Different Test Methods / Virsmu tīrišanas līdzekḷa toksiskuma novērtěšana, izmantojot dažādas testa metodes, Mater. Sci. Appl. Chem. (2016). doi:10.1515/msac-2015-0014.

[25] I. Grand, M.N. Bellon-Fontaine, J.M. Herry, D. Hilaire, F.X. Moriconi, M. Naïtali, Possible overestimation of surface disinfection efficiency by assessment methods based on liquid sampling procedures as demonstrated by in situ quantification of spore viability, Appl. Environ. Microbiol. (2011). doi:10.1128/AEM.00649-11. 